\title{
Tamm-Horsfall glycoprotein in streptozotocin diabetic rats: a study of kidney in situ hybridization, immunohistochemistry, and urinary excretion
}

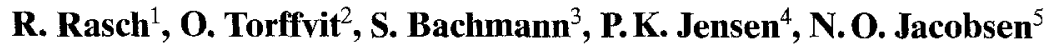 \\ ${ }^{1}$ Department of Cell Biology, Institute of Anatomy, University of Aarhus, Denmark \\ ${ }^{2}$ Department of Internal Medicine, University Hospital of Lund, Sweden \\ ${ }^{3}$ Department of Anatomy and Cell Biology, Ruprecht-Karls-Üniversität, Heidelberg, Germany \\ ${ }^{4}$ Department of Ophthalmology, Aarhus University Hospital, Kommunehospitalet Aarhus Denmark \\ ${ }^{5}$ Institute of Pathology, Aarhus University Hospital, Kommunehospitalet Aarhus Denmark
}

\begin{abstract}
Summary Tamm-Horsfall glycoprotein, present only in the kidney thick ascending limb of Henle's loop, was studied here in streptozotocin diabetic rats. Tamm-Horsfall glycoprotein mRNA in situ hybridization was performed on snap-frozen left kidneys; the right kidneys were perfusion-fixed with $4 \%$ paraformaldehyde and embedded either in paraffin, for Tamm-Horsfall glycoprotein immunohistochemistry, or in Epon for stereologic measurements. The length of the thick ascending limb of Henle's loop and the amount of glycogen were measured and the ultrastructure of the cells was evaluated. Urinary excretion of Tamm-Horsfall glycoprotein, calcium, magnesium and albumin was measured. After 10 and 50 days' duration of diabetes, kidney weight increased 20 and $41 \%$, respectively and the length of the thick ascending limb of Henle's loop increased 28 and $56 \%$, respectively, compared with controls. Substantial glycogen accumulations were present in the thick ascending limb of Henle's loop, and electron microscopy revealed a significant decrease in organ-
\end{abstract}

elles and basolateral membranes. After 10 and 50 days' duration of diabetes, in situ hybridization of Tamm-Horsfall glycoprotein mRNA revealed a fourfold decrease, and the immunostaining for Tamm-Horsfall glycoprotein showed a threefold decrease as measured by densitometry. However, urinary Tamm-Horsfall glycoprotein excretion rate was increased fivefold and urinary concentration about twofold. Urinary calcium excretion increased threefold and magnesium twofold, but urinary albumin excretion was not significantly increased. The increased amount of Tamm-Horsfall glycoprotein, calcium and magnesium in the urine in diabetes occurs here concomitant with severe cellular damage in the thick ascending limb of Henle's loop. [Diabetologia (1995) 38: 525-535]

Key words Diabetes mellitus, kidneys, thick ascending limb of the loop of Henle, Tamm-Horsfall glycoprotein.
Tamm-Horsfall protein (THP) was first discovered in human urine by Tamm and Horsfall in 1950 [1] and was later also found in rats [2] and hamsters [3]. THP is produced in the thick ascending limb of

Received: 27 April 1994 and in revised form: 11 November 1994

Corresponding author: Dr. R. Rasch, Department of Cell Biology, Institute of Anatomy, University of Aarhus, DK-8000 Aarhus C, Denmark

Abbreviations: THP, Tamm-Horsfall protein; TAL, Thick ascending limb of Henles loop, AE, Armanni-Ebstein lesion; OSOM, outer stripe of outer medulla; ISOM, inner stripe of outer medulla.
Henle's loop (TAL) [4], where a substantial part of calcium $(\mathrm{Ca})$ and magnesium $(\mathrm{Mg})$ is reabsorbed $[5$, 6]. The presence of THP can be demonstrated in the basolateral and apical membranes of the same cells, in vesicles and lysosomes $[7,8]$. The relative abundance of THP in the urine [9] indicates a possible physiological role of the protein in the TAL or in the urinary system. It has been proposed that THP is active in maintaining the relative water impermeability of the TAL [10], and the association with plasma membranes could indicate a connection with chloride transport [11]. THP inhibits virus haemagglutination [1], and an antibacterial action has been suggested since certain bacterial strains adhere 
to THP in the urine [12]. Tubular casts contain a core of THP $[13,14]$. THP may play an important role in regulating circulating levels of lymphokines, and thus the kidney may be an immuno-regulatory organ, by regulating the level of lymphokines $[15,16]$. A significant reduction in THP synthesis and excess Ca excretion is seen in hyperprostaglandin E-syndrome [17]. In spite of this knowledge about THP, its physiological significance is not yet fully established.

In diabetic patients, the presence of glycogen in the nephron was first demonstrated by Armanni and Ebstein in 1877 and designated the Armanni-Ebstein lesion (AE) [18]. In experimental diabetes, AE is present in the TAL [19] with a distribution within the nephron similar to that of the THP in normal kidneys. In cells with the AE lesion, cellular organelles and basolateral cell membrane infoldings decrease substantially [20]. In order to evaluate a possible significance of THP in diabetes and its interrelationship with the glycogen accumulations, the formation, localization, and excretion of THP were determined in rats after 10 and 50 days duration of diabetes. Urinary excretion of $\mathrm{Ca}$ and $\mathrm{Mg}$ was also determined.

\section{Materials and methods}

Animals. Female Wistar rats, body weight $122 \pm 3 \mathrm{~g}$ (mean \pm SD), were separated into three different groups each containing eight animals: i.e. controls; animals that were diabetic for 10 days (D10); and for 50 days (D50).

Diabetes was induced in the rats by i.p. injection of $90 \mathrm{mg}$ streptozotocin (Upjohn Inc., Kalamazoo, Mich., USA) per kg body weight. Diabetes developed on the second day after streptozotocin administration, as verified by glucosuria and blood glucose concentration measurements with Glucometer II (Ames Division, Miles Laboratories, Inc, Elkhart, Ind., USA) and glucostix (Ames). In the D10 animals, diabetes was induced 40 days later than in the D50 animals so that all animals were the same age at the end of the experiment. All diabetic animals were daily treated subcutaneously with small doses of Heat Treated Ultralente bovine insulin, $\mathrm{pH} \mathrm{5.5, \text {not }}$ for human use (Novo, Copenhagen, DK) [21]. During this 50day period, body weight and blood glucose concentration were measured once a week, and insulin was administered in doses designed to produce $20 \%$ lower body weight in the diabetic animals.

Kidney tissue preservation. At the end of the experiment, the animals were anaesthetized with pentobarbital, $50 \mathrm{mg} / \mathrm{kg}$ body weight, i.p.

Left kidney: after opening the abdomen, the left kidney was exposed, the renal vessels were clamped, and the kidney was removed, wiped, stripped of its capsule and cut perpendicular to the long axis of the kidney. The three middle slices were snapfrozen in isopenthane cooled in liquid nitrogen and were stored in closed vials at $-80^{\circ} \mathrm{C}$ until $\mathrm{mRNA}$ in situ hybridization could be performed.

Right kidney: perfusion fixation of the right kidney was performed retrograde through the aorta with $4 \%$ paraformaldehyde for $4 \mathrm{~min}$ at a pressure of $140 \mathrm{~mm} \mathrm{Hg}$ [22]. Only kidneys that blanched immediately, indicating optimal perfusion, were included in the study. After fixation of the tissue, the left kidney was removed, weighed, and cut in $2-\mathrm{mm}$ slices perpendicular to the long axis of the kidney [23]. Every second 2-mm slice was embedded in paraffin and processed for immunohistochemical staining for THP's protein. From the remaining kidney slices, five $2 \times 2-\mathrm{mm}$ randomly selected blocks were cut from the cortex, the outer stripe of the outer medulla (OSOM), and from the inner stripe of the outer medulla (ISOM), stained with osmium, and embedded in Epon (TAAB, Reading, UK).

Measurements of TAL volume fraction in kidney. On paraffinembedded kidney slices with THP immunohistochemical staining from the control kidneys the volume fraction of TAL in the individual kidney zones was measured with a point count technique.

Quantitation of TAL glycogen accumulations, the Armanni-Ebstein lesion $(A E)$, and the distal tubule $(D T)$ length. Five Eponembedded blocks were cut from cortex, OSOM and ISOM in each animal on an Ultratome III (LKB, Stockholm, Sweden). Sections $3 \mu \mathrm{m}$ thick were stained with toluidine blue and periodic acid Schiff for light microscopy. On these sections, the volume fraction of TAL containing glycogen was measured applying a point count technique [24] at a magnification of $400 \times$, and the length of the distal tubule was measured by applying a stereologic technique whereby the number of distal tubule profiles is counted within a frame [25] at a magnification of $200 \times$.

Two 3- $\mu$ m-thick Epon sections from each kidney zone per animal were re-embedded in Epon, and thin sections cut for electron microscopy [26]. The sections were stained with lead citrate and uranyl acetate and photographed in a Jeol $100 \mathrm{~B}$ electron microscope (Akishima, Tokyo, Japan), at a magnification of $13,000 \times$. From these sections, the ultrastructure of the glycogen-containing cells is described.

THP staining procedure. The perfusion-fixed, paraffin-embedded tissue was sectioned in 4- $\mu \mathrm{m}$-thick slices and immunostained with anti-Tamm-Horsfall glycoprotein antiserum (Behringwerke, Marburg, Germany) raised in rabbits against uromucoid [27]. The antiserum was diluted 1:200. The site of the antigen-antibody reaction was visualized by the peroxidase-antiperoxidase method described by Sternberger [28] and conventional staining controls were employed.

In situ hybridization. Cryostat sections $7 \mu \mathrm{m}$ thick were obtained with a cryostat microtome and mounted on glass slides coated with poly-L-lysine (Sigma, St Louis, Mo., USA). The sections were then fixed in $4 \%$ paraformaldehyde and stored in $70 \%$ ethanol at $4^{\circ} \mathrm{C}$ until further use. In situ hybridization of the kidney tissue sections was performed according to Bachmann et al. [4].

Video-based densitometry. The mRNA autoradiography and immunoperoxidase-stained renal sections from five animals in the three groups were studied in a light microscope equipped with $a \times 10$ objective, as described by Flyvbjerg et al. [29]. An image was produced directly onto the face plate of a video camera (MTI-CCD 72; Dage, Michigan City, Ind., USA). The threshold slice level of 90 for creation of binary images (black and white only) was chosen as the level clearly discriminating between pigment located in the TAL and pigments used as counterstain. The same level was used for discriminating between the autoradiographic grains and background. The microscopist was unaware of the treatment groups from which each sample was obtained and all preparations were digitized 
during one session. Three non-overlapping images were obtained from each region: cortex; OSOM; ISOM; and inner medulla. In the inner medulla, however, it was possible to obtain only one field without overlap. For each image a histogram distribution of grey values was obtained. The three histograms obtained from each animal for each region were averaged and used in a two-way analysis of variance components between groups and regions.

Urine collection. The animals were placed in metabolic cages for $4 \mathrm{~h}(08.00-12.00$ hours) during the last 3 days of the experiment. The collected urine was stored without preservatives at $-20^{\circ} \mathrm{C}$ in $2 \mathrm{ml}$ polypropylene plastic tubes. Water intake was not measured.

Preparation of rat Tamm-Horsfall protein. Tamm-Horsfall protein was prepared by precipitation with $0.58 \mathrm{~mol} / \mathrm{l} \mathrm{NaCl}$ as described previously [30]. However, the final preparation from rat urine contained a large amount of salt crystals if the following procedure was not used. The rat urine was dialysed before preparation and the final solution was dialysed four times instead of three times as for human urine. $\mathrm{NaCl}$ was added to the pool of urine mixed with an equal volume of distilled water to reach a concentration of $0.58 \mathrm{~mol} / 1, \mathrm{pH} 5-6$. The precipitate formed after $24 \mathrm{~h}$ was collected by centrifugation $(7000 \times g$ for $30 \mathrm{~min})$. The pellet was dissolved in distilled water and, after centrifugation $(7000 \times g$ for $30 \mathrm{~min})$, the precipitation process was repeated with the solute. The final solution was dialysed four times against distilled water and freeze dried.

Preparation of human THP. The preparation of human THP followed the steps above but without need for dialysis before precipitation with $\mathrm{NaCl}$, and the final solution needed to be dialysed only three times.

Electrophoresis. SDS-PAGE was performed as described by Laemmli [31] in 3-22\% linear gradient gels. These were stained with silver according to the method of Morrisey [32]. Both human and rat THP showed a similar single band corresponding to a mol. wt. of 94,000 dalton, corresponding to the monomeric molecules.

Preparation of antibodies against rat Tamm-Horsfall protein. Polyclonal antibodies were produced in the rabbits. Rat THP $(120 \mu \mathrm{g})$ with Freund's complete adjuvant (Sigma) was injected subcutaneously in the neck at three places $(100 \mu \mathrm{l})$ in two rabbits. Six and 12 weeks later, $120 \mu \mathrm{g}$ THP in Freund's incomplete adjuvant was injected. To make the antibodies react with both human and rat THP, a dose of the human THP $(100 \mu \mathrm{g})$ was given five months later in incomplete Freund's adjuvant.

Enzyme-linked immunoassay. The assay for THP followed the same steps as previously described [30]. The plates were coated with human THP. Before analyses, urine and standard were diluted in distilled water in order to de-aggregate THP. Urine was diluted ten times, and a standard serial dilution of THP, $64-4000 \mu \mathrm{g} / \mathrm{l}$, was analysed on each plate. The assay showed no difference in the standard curve whether the plates were coated with human or rat THP. Consequently, as human THP is much easier to collect and prepare, we used this antigen for the rat assay. Before analysis, urine and standard were diluted in distilled water. Urine dilution of 1:10 was used. The polyclonal antibody was diluted 1:1000 (v/v) in ELISA buffer and $100 \mu \mathrm{l}$ was added to the $100 \mu \mathrm{l}$ of test/standard sample. Thereafter, $50 \mu \mathrm{l}$ of swine-anti-rabbit alkaline phosphatase conjugate (Dako-patts, Copenhagen, Denmark), diluted 1:250 $(\mathrm{v} / \mathrm{v})$ was added. The mixture was incubated at room temperature for $3 \mathrm{~h}$. After washing, enzyme activity was determined as previously described [30]. Samples were analysed in duplicate and the coefficient of variation was calculated from 24 single measurements of the same urine on each plate. The intraassay variation was calculated on 3 days on $3 \times 24=72$ cumulative measurements.

Standard curve for THP. The standard curves of serial dilutions $(64-4000 \mu \mathrm{g} / \mathrm{l})$ for human and rat antigen were parallel and inhibited the antibody to similar degree. The human THP was easier to prepare and consequently this was used for the standard. The dilution curve of rat urine was similar to the THP standard curve, thus confirming that the antigen measured was actually THP.

Sensitivity of the assay. The detection limit was $64 \mathrm{ng} / \mathrm{ml}$ or 6.4 ng. The intraassay coefficient of variation was $17 \%$ and the interassay variation was $27 \%$ at urine concentration of 3.8 $\mathrm{mg} / \mathrm{l}$ (diluted 1:10), which fell at the $50 \%$ intercept of the standard curve. The intraindividual coefficient of variation was $31.8 \%$ in diabetic rats and $44.6 \%$ in control rats.

Human and rat THP was added in amounts of 1,2, 5, 7 and $9 \mu \mathrm{g}$ to urine samples with concentrations of 4.1 and $3.1 \mathrm{mg} / \mathrm{ml}$. The mean recovery of the amount added was $117 \%$ (range 93$147 \%)$ and $100 \%(75-121 \%)$.

Rat albumin assay. The assay was performed as previously described for human albumin [33]. Rat albumin (Sigma) and clonal rabbit anti rat (Nordic Immunolog Laboratories, Tillberg, The Netherlands) were used. The latter was diluted 1:2,000 (v/v). The detection limit was $16 \mu \mathrm{g} / \mathrm{l}$ or $1.6 \mathrm{ng}$. The intraassay and the interassay coefficients of variation were 11.8 and $12.8 \%$. The dilution curve of urine was parallel to the standard curve. The mean recovery of added albumin $(48,91,166,286$ and $444 \mu \mathrm{g}$ ) to urine (31 mg/l) was 102\% (range 93-114\%).

$\mathrm{Ca}$ and $\mathrm{Mg}$ measurements. Urine $\mathrm{Ca}$ and $\mathrm{Mg}$ were analysed by a colorimetric technique (EKTA chem-analyzer $700 \mathrm{XR}-\mathrm{C}$; instrument KODAK, Rochester, NY, USA).

\section{Statistical analysis}

The values in the different groups of rats were first compared with the Kruskall Wallis' test and, if a significant difference was found, the values were compared with the Mann-Whitney's test. When comparing data on different kidney zones in the rats we used Friedman's two-way analysis of variance and, if significant differences were found, Wilcoxons' signed rank test. The frequency distribution of urinary Tamm-Horsfall protein concentration and excretion rate and the albumin excretion rate is known to become Gaussian on $\log ^{10}$ transformation [30] and the values are therefore given as geometric mean $\mathrm{x} /$ tolerance factor. All tests were two-tailed and the level of significance $p<0.05$.

\section{Results}

Animals. Control animals and D50 animals weighed $122 \pm 3 \mathrm{~g}$ (mean $\pm \mathrm{SD}$ ) at the start of the experiment. When diabetes was induced in the D10 animals, 40 days later, these animals weighed $204 \pm 12 \mathrm{~g}$.

At the end of the experiment the body weight in the controls was $241 \pm 12 \mathrm{~g}$. The body weight of the D10 was $203 \pm 9 \mathrm{~g}$ and in the D50 animals $193 \pm 7 \mathrm{~g}$. The blood glucose concentration during the experi- 


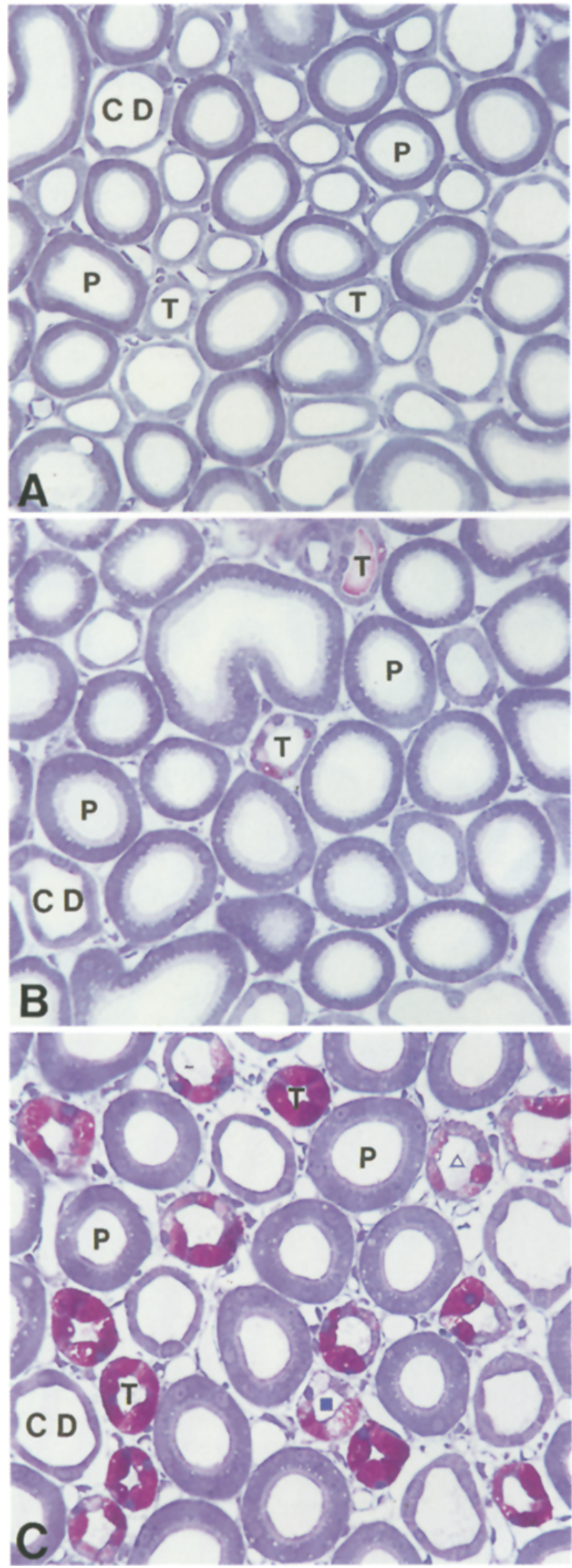

ment was $5.8 \pm .6 \mathrm{mmol} / \mathrm{l}$ in the control animals and at the termination of the experiment it was $17 \pm 1.7 \mathrm{mmol} / \mathrm{l}$ in $\mathrm{D} 10$ and $19 \pm 1.4 \mathrm{mmol} / 1$ in $\mathrm{D} 50$ animals. Blood glucose concentration after $4 \mathrm{~h}$ fasting in the metabolic cages was significantly lowered, from $19 \pm 1.7$ to $15 \pm .5 \mathrm{mmol} / 1$, but the animals were still glycosuric.

Kidney weight. Kidney weight increased significantly from $1004 \pm 67 \mathrm{mg}$ in the controls to $1207 \pm 110 \mathrm{mg}$ in D10, $p<0.0004$ and $1416 \pm 102 \mathrm{mg}$ in the D50 animals, $p<0.0004$.

TAL volume fraction in kidney zones. In normal animals the volume fraction of TAL was $4 \pm 0.2 \%$ in the cortex, $12 \pm 0.6 \%$ in the OSOM, and $24 \pm 2.3 \%$ in the ISOM.

Glycogen accumulations. Controls contained no glycogen in TAL, Figure 1A. In the D10 animals, the TAL cells contained focal accumulations of glycogen, but the basic structure of the cells was preserved. In D10, the fraction of glycogen in the TAL profiles was $10.7 \pm 0.3 \%$ in the cortex and $3.5 \pm 0 \%$ in the OSOM, Fig. 1B. In the D50 rats (Fig. 1C), the $73 \pm 4.2 \%$ glycogen dominated the cells of the cortical TAL to such an extent that very few organelles were seen compared with controls (Fig. 2). The few mitochondria were located along the plasma membrane and the cell had lost its basolateral interdigitations. Glycogen accumulations were also present in the OSOM, $7.8 \pm 0.2 \%$. No glycogen was present in the ISOM.

Tubule length. The total length of the distal tubule per kidney increased from $188 \pm 17$ meters $(\mathrm{m})$ in the controls to $240 \pm 29 \mathrm{~m}$ and $294 \pm 37 \mathrm{~m}$ in the D10 and D50, $p<0.0009$ in D10 and D50 compared with controls.

Fig. 1. A Light micrograph of cortex from a normal animal. Proximal tubules (P), thick ascending limbs of Henle's loop (T) and collecting ducts (CD) are seen. No glycogen accumulations are present. Staining PAS and toluidine blue. Magnification $\times 400$. B Light micrograph of cortex from a 10-day diabetic animal. Proximal tubules (P), thick ascending limbs of Henle's loop ( $\mathrm{T}$ ) and collecting ducts (CD) are seen. In the T, glycogen accumulations appear as red. Magnification $\times 400$. $\mathbf{C}$ Light micrograph of cortex from a 50-day diabetic animal. Proximal tubules (P), thick ascending limbs of Henle's loop (T) and collecting ducts (CD) are seen. In the T, glycogen accumulations appear as red occupying the whole TAL profile. TAL cells marked with $\triangle$ have a varying amount of glycogen, and in TAL cells marked with $\square$ the glycogen has been washed out during preparation and the cells appear empty. Glycogen cannot be seen at the light microscope level in normal animals with the method applied. Glycogen accumulations, however, appear red and they are very pronounced in the cortical region after 50 days duration of diabetes. Magnification $\times 400$ 


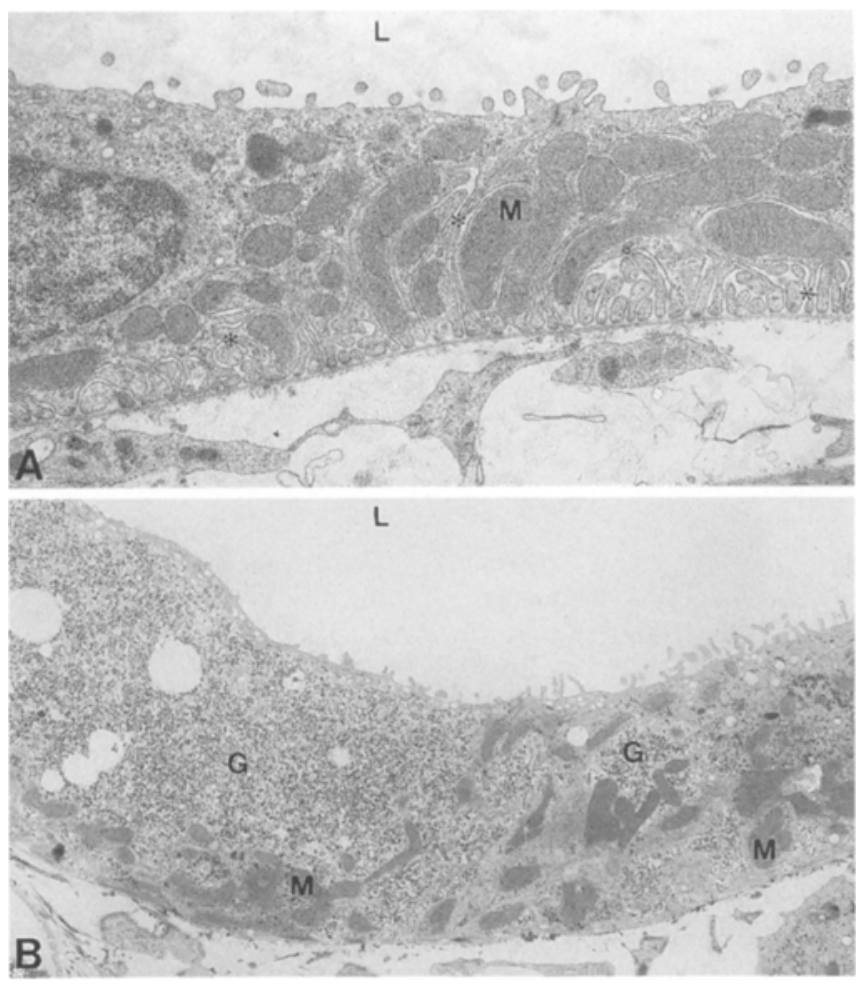

Fig. 2. A Electron micrograph from a normal TAL. Glycogen is seen as individual particles indistinguishable from ribosomes, which also are seen as individual particles or as attached to the rough endoplasmatic reticulum. L, lumen; $\mathrm{M}$, mitochondria; * basolateral membrane, magnification $\times 13,000$. B Electron micrograph of TAL from an animal with 50 days duration of diabetes. Two cells are shown. In the cell to the left, glycogen particles are seen in large amounts. The mitochondria are located in the periphery of the cell and no basolateral infoldings of the plasma membrane can be seen. In the cell to the right, glycogen accumulations, $\mathrm{G}$, can be seen between mitochondria. L, lumen; M, mitochondria; nearly all the particles seen on the micrograph are glycogen. Magnification $\times 13,000$

Densitometry of THP $m R N A$ and THP tissue staining. No change is seen in the ISOM. In Fig. 3 the distribution of the mRNA at low magnification can be seen. At this magnification very few silver grains are seen after 50 days' duration of diabetes. Figures 4 shows a larger magnification of the OSOM, here, too, the decrease in number of autoradiographic grains is very obvious. Figure 5 shows the decrease in the densitometric recordings in the cortex, OSOM, and ISOM. After only 10 days, the decrement is already significant in the cortex and OSOM.

As shown in Figs. 6A and $7 \mathrm{~A}$, THP immunostaining is an excellent marker of the entire outline of the TAL. A significant fall in staining intensity in the cortex after both 10 and 50 days of diabetes in all zones can be seen in Figs. 6B, C and 7B, C. The results of the measurements are shown in Fig. 8.

In normal kidneys, the densitometric measurements showed that the autoradiography for mRNA and immunostaining for THP was least pronounced in the cortex, as a consequence of the small percent-

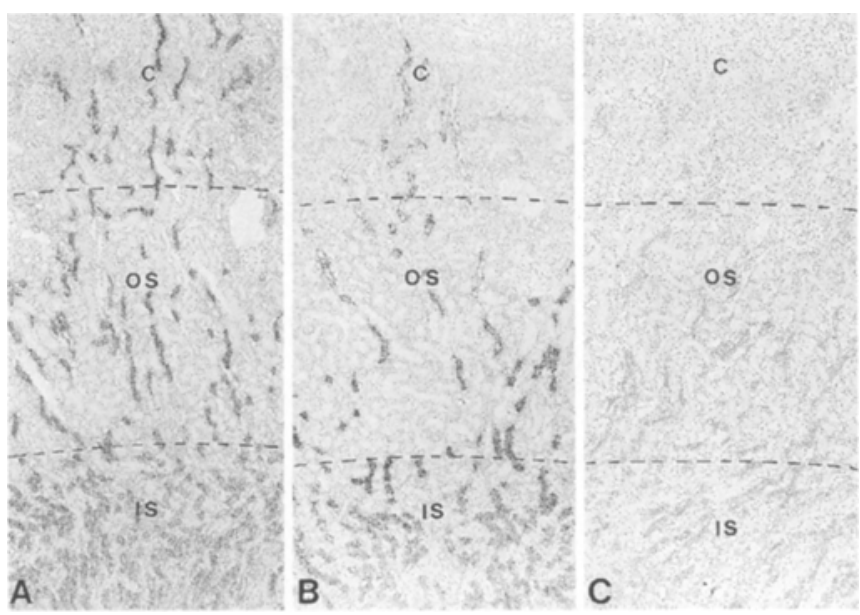

Fig. 3 A-C. In situ hybridization of THP mRNA at low magnification in cortex (C), outer stripe of outer medulla (OS) and inner stripe of outer medulla (IS) shows the autoradiographic grains over the cells of the thick ascending limb of Henle's loop (TAL) in the medullary rays in the cortex. More profiles with grains are seen in the OS and most in the IS, in accordance with the fractions of TAL in the kidney zones in normal animals. (A) In the 10-day diabetic animal (D10), (B) and the 50-day diabetic animals (D50), (C) a decrease in autoradiographic grains is obvious over the TAL cells in the $C$, OSOM and ISOM. Magnification $\times 50$

age of TAL present here $(4 \%)$. THP is most pronounced in the OSOM and less pronounced in the ISOM. The reason for lower intensity in the ISOM, where most TAL tissue is actually present $(24 \%)$ is that the intensity of the staining decreases from OSOM to ISOM. However, when calculated as total amount of TAL tissue, the distribution between cortex-OSOM and ISOM is $1: 1.2: 1.8$, since the volume fraction of cortex in the kidney is $50 \%$, of OSOM $30 \%$, and of ISOM only $15 \%$ [20], indicating that the overall decrease in cortical THP is considerable.

Urine excretion. The urine volume at the termination of the experiment was $13 \pm 6.6 \mathrm{ml} / 24 \mathrm{~h}$ in the controls. It was $20.8 \pm 13.1$ in the D10 animals and $34.2 \pm 34$ in the D50 animals (Table 1 ).

Urinary THP excretion rate and concentration. The THP excretion rate was increased threefold after 10 days and fivefold after 50 days duration of diabetes (Table 1). The THP concentration was also increased in the diabetic rats after 10 days duration of diabetes but not after 50 days duration of diabetes (Table 1 ). The THP excretion rate $(r=0.58 ; \mathrm{p}<0.001)$, but not the THP concentration, was correlated to diuresis.

Urinary albumin excretion. In control rats, the albumin excretion rate was $167 \mu \mathrm{g} /$ day (61-648) (median, range). The excretion rate was not significantly increased after 10 days of diabetes, $107 \mu \mathrm{g} /$ day (39$145)$ or 50 days of diabetes, $213 \mu \mathrm{g} /$ day $(23-2690)$. 

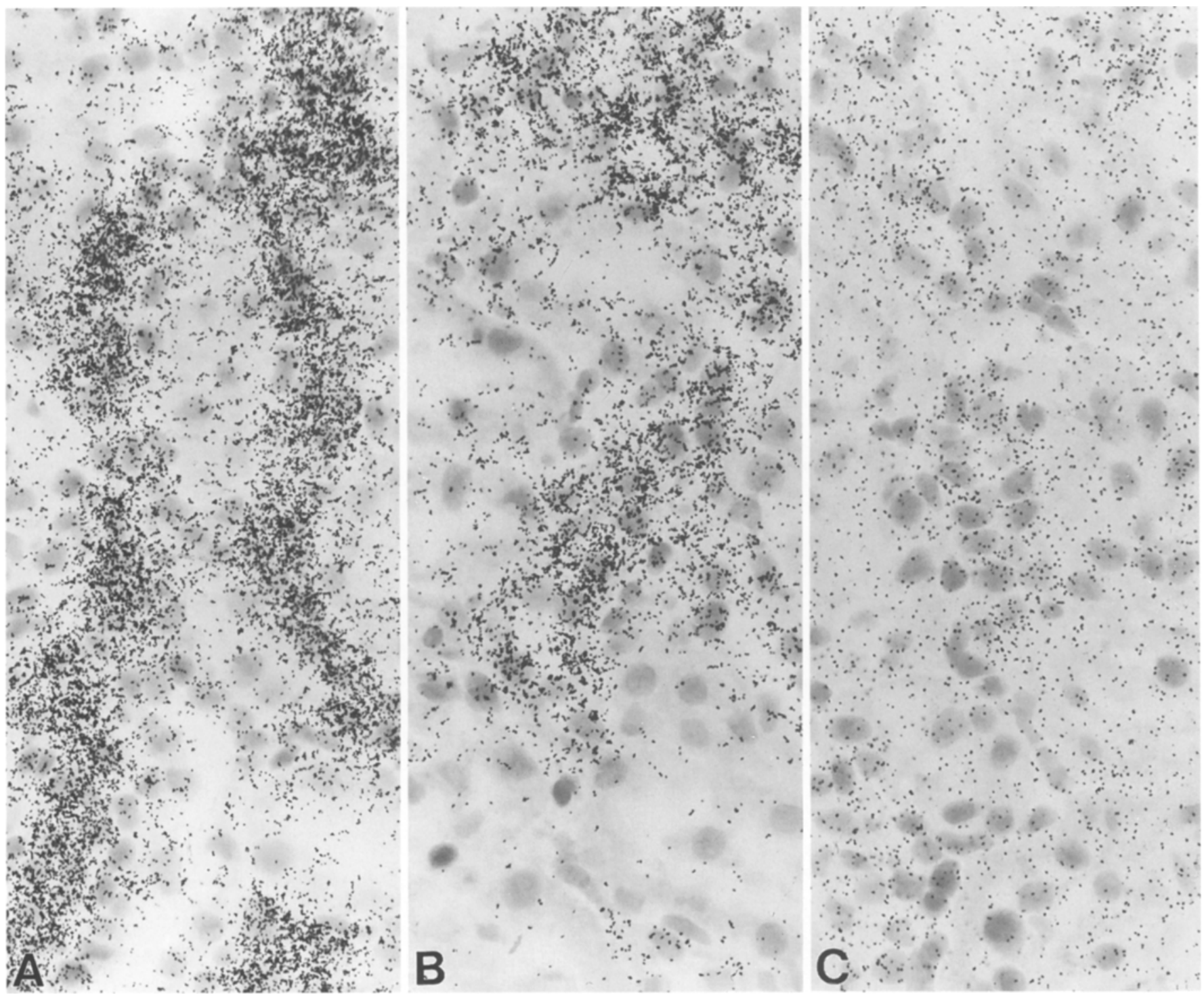

Fig. 4A-C. In situ hybridization of THP mRNA at higher magnification from the outer stripe of outer medulla. The amount of autoradiographic grains over the cells of the thick ascending limb of Henle's loop (TAL) is pronounced in the control, (A). In the 10-day diabetic animals (B) fewer grains are seen, and in the 50-day diabetic animals $(\mathbf{C})$, a pronounced reduction of the amount of grains in the TAL is seen. Magnification $\times 600$

Urinary $\mathrm{Ca}$ and $\mathrm{Mg}$ excretion. The Ca excretion increased significantly after both 10 and 50 days duration of diabetes (Table 1). The Mg excretion showed the same pattern (Table 1 ). The THP excretion correlated to the $\mathrm{Ca}$ excretion $(r=0.71, p<0.001)$ and to the $\mathrm{Mg}$ excretion $(r=0.71, p<0.001)$.

\section{Discussion}

A few months of experimental diabetes led to glycogen accumulations in TAL, decrease in tissue THP mRNA and tissue THP immunostaining; at the same time there was an increase in THP, $\mathrm{Ca}$, and $\mathrm{Mg}$ excretion in the urine. Although classic symptoms of nephropathy with increased urinary albumin excretion rate were not yet present at this stage, the kidney structure was abnormal.

The structural abnormalities in experimental diabetes start with kidney growth within days [34-36] and the growth has been studied in detail after a few months of diabetes [37]. It is systematic, i.e. the volume fraction in the individual tissue components in the diabetic kidneys is about the same compared with control animals, with the exception that glomeruli are relatively smaller [37]. In diabetic animals, the distal tubule becomes longer [20], its diameter is increased, and the cells are higher. The growth of the cells in the diabetic distal tubule is characterized by a $16 \%$ increase in cell size and a $36 \%$ increase in cell number [35], this in fact also occurs in the proximal tubule. If diabetes is treated meticulously from the onset of the disease, it is possible to prevent renal structural deterioration $[38,39]$. After months' dura- 


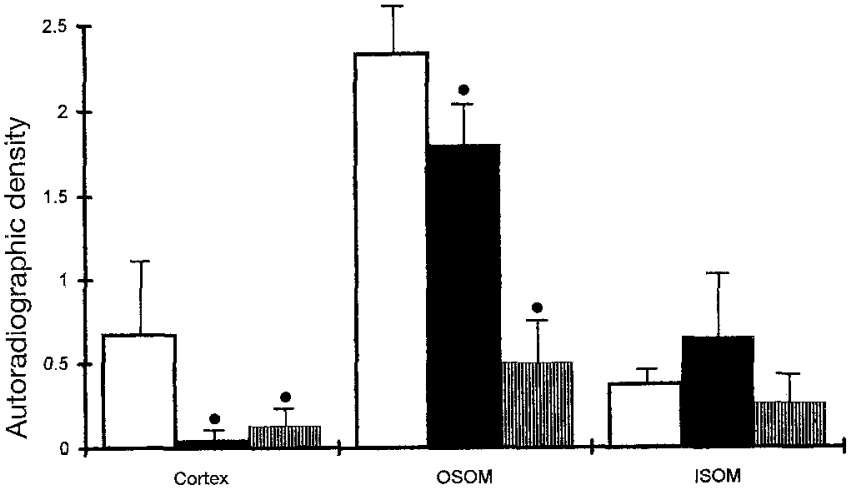

Fig. 5 Total mRNA, as assessed by densitometric measurements of the autoradiographic grains over the tissue, in cortex, outer stripe of outer medulla (OSOM) and inner stripe of outer medulla (ISOM). The $\mathrm{x}$-axis shows the kidney zones in the three groups, and the $y$-axis the autoradiographic density as grey level. A decrease in the amount of autoradiographic grains can be seen in the cortex and the OSOM in diabetic animals. Control animals $\square$, in 10-day diabetic animals $\square$ and in 50 -day diabetic animals $\|$ illi. $\bullet p<0.04$ compared with controls

tion of diabetes and hyperglycaemia it is possible to nearly normalize kidney weight in diabetic animals by normalization of blood glucose concentration, and the $\mathrm{AE}$ shows total regression after only 15 days intensive insulin treatment $[37,40]$.

In normal rats, TAL is present in the ISOM, OSOM, and cortex. Ultrastructurally, the normal TAL shows an axial heterogeneity [41-43]. The TAL cells in the OSOM and ISOM are higher, have more basal cellular invaginations, more mitochondria, and $\mathrm{NA}^{+}, \mathrm{K}^{+}$-ATPase staining of the membranes compared with the cells in the cortex, and throughout the normal TAL glycogen is not seen as accumulations. The TAL ends abruptly, either at the macula densa or shortly after [43]. In the TAL, the active transport of $\mathrm{Na}^{+}$out of the cells without concomitant water transport is the foundation of the countercurrent multiplier system which forms the concentration gradient from cortex to medulla in the kidney.

In normal rats, THP is formed continuously in the TAL $[13,44]$. Of all the cells in the body, only the TAL cells in the kidney form THP. Turnover studies indicate a half life of $9 \mathrm{~h}$ in rabbits [45] and 3-168 h
[9] in humans. It is produced in the rough endoplasmic reticulum, passes through the Golgi apparatus and vacuoles, and is then inserted into the cell membranes, into both the apical and the basolateral membranes $[8,10]$. THP is attached to the outside of the cell membrane, where it binds covalently to glycosylphosphatidylinositol [46-48]. The lipid-linked THP is released into the urine after loss of its hydropic anchor, probably by action of a phospholipase or a protease [48]. THP is then released into the urine where it constitutes about half of the total amount of proteins present in normal urine. In the TAL, THP probably acts as a water barrier that allows ion movement across the TAL [49]. However, neither the reason for the formation, its presence in and on the TAL cells, nor the function of the THP in the urine is fully understood.

The production of the THP is independent of urinary volume and transport rate of solutes in the TAL [2] in normal rats but the excretion of urinary THP increases after increase in protein intake [2].

In the TAL, $25 \%$ of the kidney $\mathrm{Ca}$ reabsorption takes place. $\mathrm{Ca}$ is reabsorbed by a passive, paracellular, voltage, lumen positive, driven mode and by a transcellular pathway in the cortex [5]. The major part of $\mathrm{Mg}$ reabsorption takes place in the TAL [6], and although the reabsorption mode is different for the two ions, they have in common that the reabsorption in the TAL is in part transcellular and influenced by hormones.

In the diabetic kidney, only the TAL cells exhibit massive glycogen accumulations. No other cells in the organism accumulate that much glycogen, except liver cells; but the latter are not in a degenerative state and they accumulate $\alpha$ particles, whereas the glycogen in the TAL accumulates in $\beta$ particles [50]. Normal kidneys, like the liver, participate in blood glucose concentration regulation, albeit much less, and this function is probably located in the collecting duct [51].

In D10, small accumulations of glycogen are present in cortex and OSOM TAL (Fig.6). In D50, many severely affected cells are loaded with glycogen in cortex, fewer in OSOM, and they are not present in ISOM (Fig.7).

Table 1. Tamm-Horsfall protein (THP) concentration and excretion rate. Excretion rate of calcium and magnesium and diuresis in control rats (C) and in rats with 10 (D10) and 50 (D50) days duration of diabetes

\begin{tabular}{|c|c|c|c|}
\hline & Controls & D 10 & D 50 \\
\hline$n$ & 12 & 12 & 12 \\
\hline THP concentration $(\mu \mathrm{g} / \mathrm{ml})$ & $1.5 \times / 1.5$ & $2.9 \times / 1.6^{\mathrm{a}}$ & $2.6 \times / 2.9$ \\
\hline THP excretion rate $(\mu \mathrm{g} /$ day $)$ & $15.7 \times / 1.7$ & $45.4 \times 11.6^{\mathrm{b}}$ & $78.7 \times / 2.9^{\mathrm{b}}$ \\
\hline Magnesium ( $\mu \mathrm{mol} / \mathrm{day})$ & $199.8 \pm 65$ & $266.6 \pm 95$ & $341.6 \pm 128^{a}$ \\
\hline Diuresis (ml/day) & $13.0 \pm 6.6$ & $20.8 \pm 13.1$ & $34.2 \pm 13.4^{c}$ \\
\hline
\end{tabular}

a $2 p<0.01,{ }^{\mathrm{b}} 2 p<0.001$ compared with control rats. ${ }^{\mathrm{c}} 2 p<0.05$ compared with rats with 10 days duration of diabetes. Values are given as geometric mean $x /$ tolerance or as mean $\pm \mathrm{SD}$ 


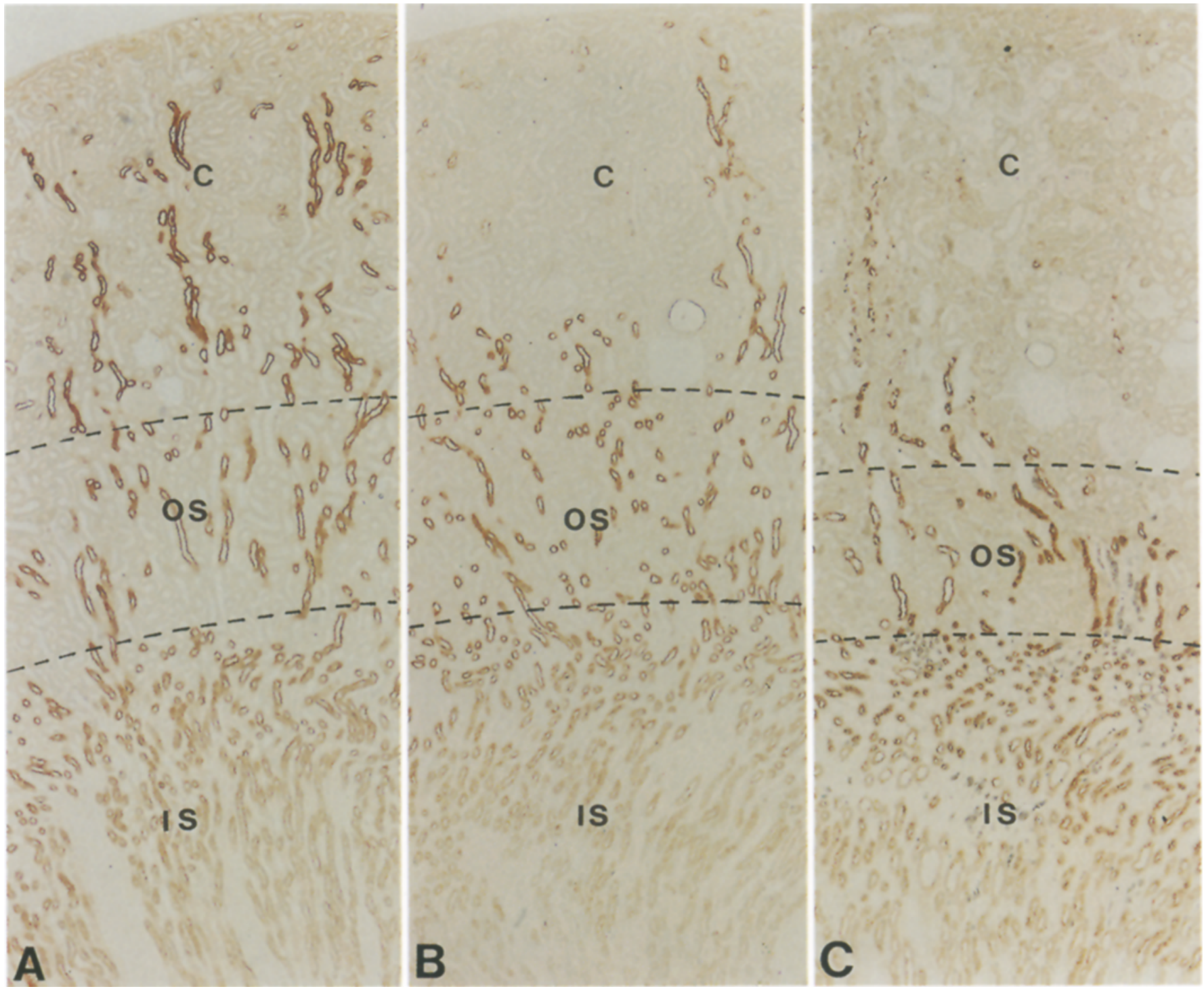

Fig. 6A-C. Immunohistochemical peroxidase staining of THP in cortex $(C)$, outer stripe of outer medulla (OS) and inner stripe of outer medulla (IS) without counterstaining. The brown reaction product from the immunohistochemical procedure reveals the localization of THP in kidney tissue to be in the thick ascending limb of Henle's loop (TAL). In cortex, the THP is seen only in the medullary rays. In OS, more profiles are seen but most TAL profiles are present in the IS, as also documented in the measurements of the TAL fraction in the various kidney zones. In the 10-day diabetic animals (D10) the staining in the cortex, OS and IS is decreased, and in the 50-day diabetic animals (D50) a pronounced decrease in staining is seen. Magnification $\times 25$

In normal rats, both the mRNA and the THP immunohistochemical staining are most pronounced where the glycogen accumulations appear in diabetes, and the decrease in THP mRNA and immunohistochemical staining occurs in the same cells in diabetes, and thus the heterogeneity of the normal TAL is reflected in the distribution of the abnormalities in the diabetic TAL.
Kidney weight and THP urinary excretion rate increased, and part of the increment in THP excretion can possibly be explained by the $40 \%$ increase in kidney weight in diabetes. The decrease in densitometric measurements of mRNA and immunohistochemical staining is not due merely to a smaller volume fraction of TAL cells in diabetes, since volume fraction of distal tubules in diabetes is the same as in controls [37], and the explanation must thus be sought in the abnormalities within the cells of the TAL.

In diabetic animals, the food intake is increased about $40 \%$ compared with controls [52]. The protein content in the fodder is $18 \%$, the increase in protein intake is much smaller than the increment in protein intake that has been shown to provoke an increase in THP urinary excretion [53].

The rats in the present study had normal excretion rate of albumin and would therefore not fulfill the criteria of incipient diabetic nephropathy with microalbuminuria, and thus an increase in THP excretion 

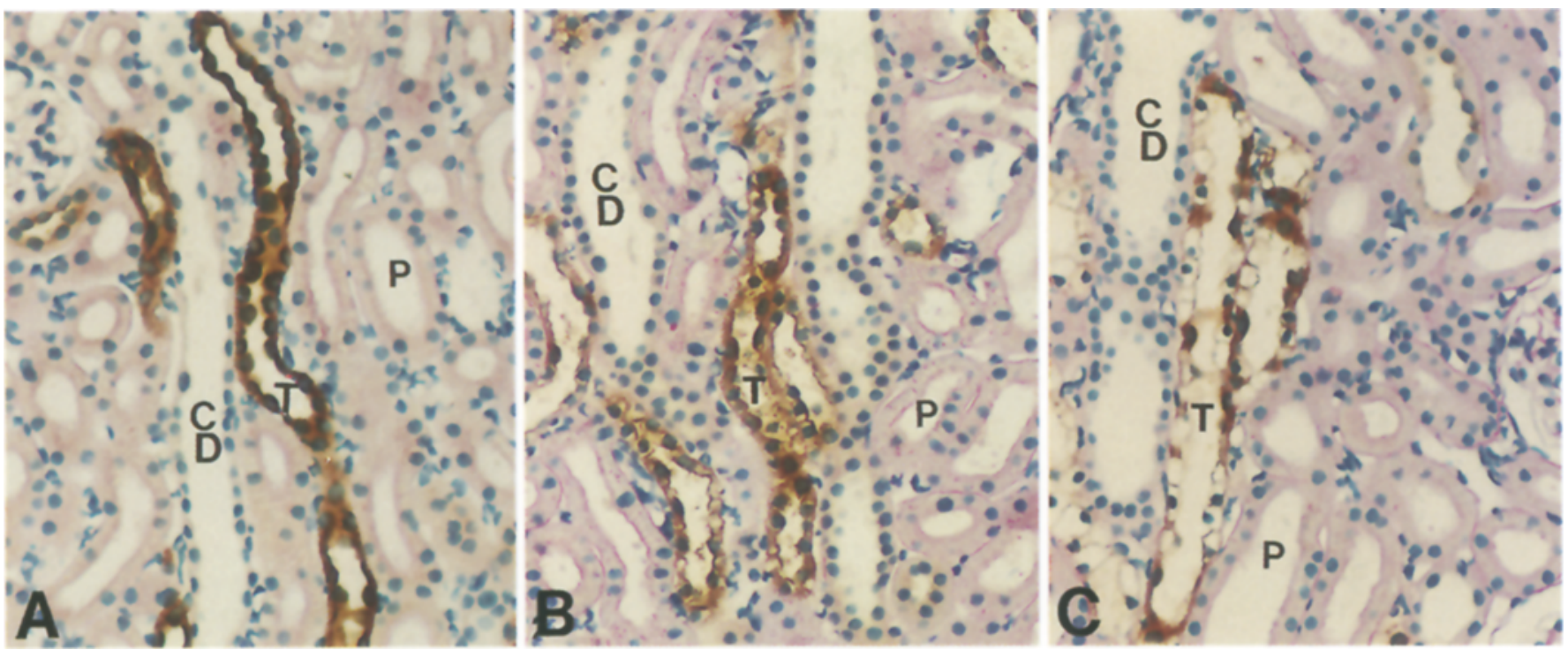

Fig. 7A-C. Immunohistochemical peroxidase staining of THP in cortex tissue sections which are also stained with PAS and haematoxylin. The brown reaction product from the immunohistochemical procedure shows THP in kidney tissue to be located in the thick ascending limb of Henle's loop (TAL). All the TAL cells are darkly stained throughout in the controls (A). In the 10-day diabetic animals, (B) the staining in the TAL cells (T) is less pronounced, and in the 50-day diabetic animals $(\mathbf{C})$, many cells in the TAL (T) appear totally devoid of THP immunohistochemical staining whereas others contain THP staining. The empty-appearing TAL cells are the glycogen containing cells, but the glycogen washes out during the tissue embedding procedure for paraffin. $P$, proximal tubules; T, TAL; CD, collecting ducts. Magnification $\times 300$

rate is an earlier indicator of structural kidney abnormalities than urinary albumin excretion rate.

The paradox that tissue THP and mRNA are decreased and yet an increase in THP urinary excretion is seen could have different explanations. Retention of THP on the TAL cells could be decreased. The THP molecule in diabetes, as it appears in the urine, has a different composition, reduced surface charge density [54], and increased glucose content [55] which could possibly contribute to a decreased binding capacity to glycosyl-phosphatidylinositol on the cell membranes [46]. Some of the increased amount of THP, however, may come from within the ISOM. No glycogen was found in the ISOM, and considering that nearly half of the total amount of TAL is located here, without accumulations of glycogen and with only a small decrease in THP mRNA and tissue immunostaining, it is possible that this region to some extent may compensate for a decreased formation of THP in the cortex and OSOM.

Many abnormalities are present in the diabetic kidney and, taking the serious damage of the TAL into consideration, this may influence the rest of the kidney.
The AE lesion causes a decrease in mitochondria and basolateral cell membranes, and diabetes may hereby affect the activity of the $\mathrm{NA}^{+}, \mathrm{K}^{+}$-ATPase which is localized in the membranes. The decrease in THP in diabetes may affect the water impermeability in this segment of the nephron $[10,49]$. The severe cellular damage of the TAL cells may influence the reabsorption of substances in the TAL. The increased Ca and $\mathrm{Mg}$ excretion in the urine point to such a decreased ability to reabsorb these ions. Since the cellular damage is localized in the TAL which is just proximal to the macula densa and the juxtaglomerular apparatus and hereby the autoregulation of the kidney via the tubuloglomerular feedback it is possible that the abnormalities in the glomerular filtration rate [56-58] known to be present in the diabetic kidney originate from the TAL. The abnormal THP, with a possible lack of ability to stay attached to the cell membrane, may provoke an immunologic response. THP functions as a glycoprotein that specifically binds to and regulates cytokines, including interleukin- 1 and tumour necrosis factor $[15,59]$ and it has been proposed that the THP could act as a specific ligand regulating circulating levels of interleukin (IL- $1 \alpha, \mathrm{IL}-1 \beta$ ) and tumour necrosis factor thus playing an important role for the circulating lymphokines and for the naturally occurring antibodies making the kidney a major immunoregulatory organ [60]. In diabetes there are accumulations of immunoglobulins in the mesangium [61], and the abnormal TAL in diabetes may possibly be the structure that initiates the immunological reactions in the glomeruli that may be of significance for the development of diabetic nephropathy.

The present study indicates that the earliest sign of a possibly reversible diabetic nephropathy may be an increased THP, Ca and $\mathrm{Mg}$ excretion rate which according to the present investigations also indicates the presence of enlarged kidneys with severe abnormalities in the TAL. 


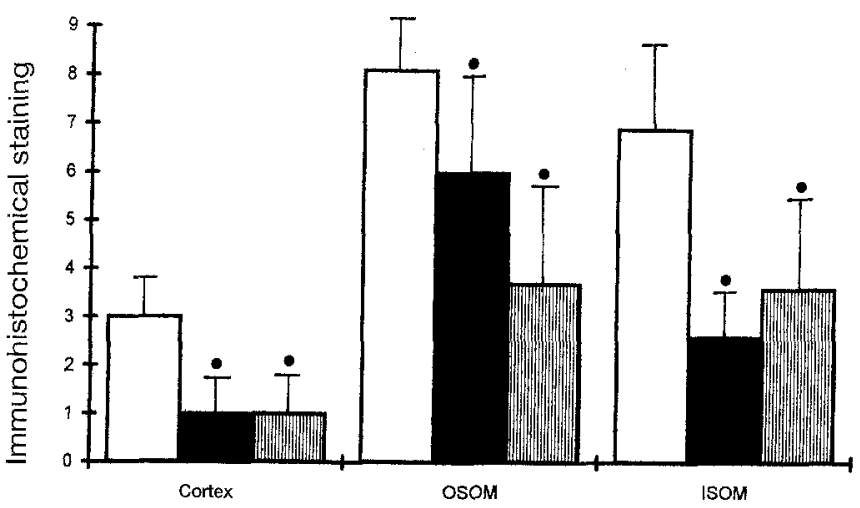

Fig. 8 Total tissue THP peroxidase immunostaining as measured by densitometry of the brown staining in cortex, outer stripe of outer medulla (OSOM) and inner stripe of outer medulla (ISOM) in control animals $\square$, in 10-day diabetic animals and in 50-day diabetic animals $\|$. The $\mathrm{x}$-axis shows the kidney zones in the three groups, and the y-axis the immunostaining as grey level. It can be seen that the total dye in controls is most pronounced in the OSOM, less is seen in the ISOM, least in the cortex where the fraction of TAL only is $3.5 \%$. In the diabetic animals, a significant fall is seen in the cortex, OSOM and ISOM, $\bullet p<0.04$ compared with controls. The values given are the mean values from all animals measured, the tolerance factor $(\mathrm{X} /)$ can be seen in the text

Acknowledgements. We thank Ms. H. Weiling and Ms. B. Grann for technical assistance. The study has been supported by the Novo Foundation, the Danish Diabetes Association, the Danish Medical Research Council and Fonden til Lagevidenskabens Fremme, the Swedish Trygg-Hansa Research Foundation, the Swedish Society of Medicine, the Royal Physiographic Society, Lund, the Medical Faculty, University of Lund, the Tore Nilsson Foundation, Sweden. Deutsche Forschungsgemeinschaft Ba 700/10/1.

\section{References}

1. Tamm I, Horsfall FL (1950) Characterization and separation of an inhibitor of viral hemagglutination present in urine. Proc Soc Exp Biol Med 74:108-114

2. Bachmann S, Dawnay AB, Bouby N, Bankir L (1991) Tamm-Horsfall protein excretion during chronic alterations in urinary concentration and protein intake in the rat. Renal Physiol Biochem 14:236-245

3. Sikri KL, Foster CL, Bloomfield FJ, Marshall RD (1979) Localization by immunofluorescence and by light- and electron-microscopic immunoperoxidase techniques of Tamm-Horsfall glycoprotein in adult hamster kidney. Biochem J 181:525-532

4. Bachmann S, Metzger R, Bunnemann B (1990) TammHorsfall protein-mRNA synthesis is localized to the thick ascending limb of Henle's loop in rat kidney. Histochemistry $94: 517-523$

5. Costanzo LS, Windhager EE (1992) Renal regulation of calcium balance. In: Seldin DW, Giebisch G (eds) The Kidney. Physiology and pathophysiology, vol 2. Raven Press, New York, pp 2375-2393

6. Quamme GA (1992) Magnesium. Cellular and renal exchanges. In: Seldin DW, Giebisch G (eds) The Kidney. Physiology and pathophysiology, vol 2. Raven Press, New York, pp 2339-2355
7. Sikri KL, Foster CL, MacHugh N, Marshall RD (1981) Localization of Tamm-Horsfall glycoprotein in the human kidney using immuno-fluorescence and immuno-electron microscopical techniques. J Anat 132:597-605

8. Bachmann S, Koeppen-Hagemann I, Kriz W (1985) Ultrastructural localization of Tamm-Horsfall glycoprotein (THP) in rat kidney as revealed by protein A-gold immunocytochemistry. Histochemistry 83:531-538

9. Lynn KL, Shenkin A, Marshall RD (1982) Factors affecting excretion of human urinary Tamm-Horsfall glycoprotein. Clin Sci 62:21-26

10. Hoyer JR, Sisson SP, Vernier RL (1979) Tamm-Horsfall glycoprotein: ultrastructural immunoperoxidase localization in rat kidney. Lab Invest 41:168-173

11. Wirdnam PK, Milner RD (1984) Tamm-Horsfall glycoprotein release from rat kidney cortex slices in vitro. Clin Sci 67:529-534

12. Orskov I, Ferencz A, Orskov F (1980) Tamm-Horsfall protein or uromucoid is the normal urinary slime that traps type 1 fimbriated Escherichia coli. Lancet I:887 [letter]

13. Fletcher AP, McLaughlin JE, Ratcliffe WA, Woods DA (1970) The chemical composition and electron microscopic appearance of a protein derived from urinary casts. Biochim Biophys Acta 214:299-308

14. Patel R, McKenzie JK, McQueen EG (1964) Tamm-Horsfall urinary mucoprotein and tubular obstruction by casts in acute renal failure. Lancet I:457-461

15. Hession C, Decker JM, Sherblom AP et al. (1987) Uromodulin (Tamm-Horsfall glycoprotein): a renal ligand for lymphokines. Science 237:1479-1484

16. Pennica D, Kohr WJ, Kuang WJ et al.(1987) Identification of human uromodulin as the Tamm-Horsfall urinary glycoprotein. Science 236:83-88

17. Schrother J, Timmermans G, Seyberth HW, Greven J, Bachmann S (1993) Marked reduction of Tamm-Horsfall protein synthesis in hyperprostaglandin E-syndrome. Kidney Int 44:401-410

18. Armanni L (1877) Fünf Autopsien mit histologischen Untersuchungen und klinischer Epicrise. In: Cantani A (ed) Der Diabetes Mellitus. Denickes Verlag, Berlin, pp 315-329

19. Holck P, Rasch R (1993) Structure and segmental localization of glycogen in the diabetic rat kidney. Diabetes 42:891-900

20. Rasch R (1984) Tubular lesions in streptozotocin-diabetic rats. Diabetologia 27:32-37

21. Rasch R (1979) Control of blood glucose levels in the streptozotocin diabetic rat using a long-acting heat-treated insulin. Diabetologia 16:185-190

22. Maunsbach AB (1966) The influence of different fixatives and fixation methods on the ultrastructure of rat kidney proximal tubule cells. I. Comparison of different perfusion fixation methods and of glutaraldehyde, formaldehyde and osmium tetroxide fixatives. J Ultrastruct Res 15:242-282

23. Gundersen HJ, Jensen EB (1987) The efficiency of systematic sampling in stereology and its prediction. $\mathrm{J}$ Microsc 147:229-263

24. Mayhew TM, Reith A (1988) Introducing basic principles and methods of stereology and morphometry. In: Reith A, Mayhew TM (eds) Stereology and morphometry in electron microscopy. Problems and solutions. Hemisphere Publishing Corporation, New York, pp 1-12

25. Seyer-Hansen K, Hansen J, Gundersen HJ (1980) Renal hypertrophy in experimental diabetes. A morphometric study. Diabetologia 18:501-505

26. Maunsbach AB (1978) Electron microscopic analysis of objects in light microscopic sections. Proc IX Int Congr Electron Microscopy, Toronto II:80-81 
27. Eriksen EF, Richelsen B, Gesser BP, Jacobsen NO, Stengaard-Pedersen K (1987) Prostaglandin-E2 receptors in the rat kidney: biochemical characterization and localization. Kidney Int 32:181-186

28. Sternberger LA (1979) Immunocytochemistry, 2nd edn. John Wiley, New York

29. Flyvbjerg A, Marshall SM, Frystyk J et al.(1992) Insulinlike growth factor I in initial renal hypertrophy in potassium-depleted rats. Am J Physiol 262:F1023-F1031

30. Torffvit O, Agardh CD, Kjellsson B, Wieslander J (1992) Tubular secretion of Tamm-Horsfall protein in type 1 (insulin-dependent) diabetes mellitus using a simplified enzyme linked immunoassay. Clin Chim Acta 205:31-41

31. Laemmli UK (1970) Cleavage of structural proteins during the assembly of the head of bacteriophage T4. Nature 227:680-685

32. Morrisey J (1981) Silver stains for proteins in polyacrylamide gels: a modified procedure with enhanced uniform sensitivity. Anal Biochem 117:307-310

33. Torffvit O, Wieslander J (1986) A simplified enzyme-linked immunosorbent assay for urinary albumin. Scand J Clin Lab Invest 46:545-548

34. Rasch R, Norgaard JO (1983) Renal enlargement: comparative autoradiographic studies of $3 \mathrm{H}$-thymidine uptake in diabetic and uninephrectomized rats. Diabetologia 25:280-287

35. Nyengaard JR, Flyvbjerg A, Rasch R (1993) The impact of renal growth, regression and regrowth in experimental diabetes mellitus on numbers and sizes of proximal and distal tubular cells in rat kidney. Diabetologia 36:1126-1131

36. Nyengaard JR, Rasch R (1993) The impact of experimental diabetes mellitus in rats on glomerular capillary number and sizes. Diabetologia 36:189-194

37. Rasch R, Holck P (1991) Growth and regression of kidneys in experimental diabetes before and after insulin treatment. A morphometric study of glomeruli, tubules and interstitium. J Am Soc Nephrol 2:296(Abstract)

38. Rasch R (1979) Prevention of diabetic glomerulopathy in streptozotocin diabetic rats by insulin treatment. The mesangial regions. Diabetologia 17:243-248

39. Rasch R (1979) Prevention of diabetic glomerulopathy in streptozotocin diabetic rats by insulin treatment. Glomerular basement membrane thickness. Diabetologia 16:319324

40. Rasch R, Gotzsche O (1988) Regression of glycogen nephrosis in experimental diabetes after pancreatic islet transplantation. APMIS 96:749-754

41. Kone BC, Madsen KM (1984) Ultrastructure of the thick ascending limb of Henle in the rat kidney. Am J Anat 171:217-226

42. Kaissling B, Kriz W (1992) Morphology of the loop of Henle, distal tubule, and collecting duct. In: Windhager EE (ed) Handbook of physiology. Section 8: renal physiology, vol I. Oxford University Press, New York, pp 109-167

43. Howie AJ, Johnson GD (1992) Confocal microscopic and other observations on the distal end of the thick limb of the human loop of Henle. Cell Tissue Res 267:11-16

44. Bjugn R, Flood PR (1988) Scanning electron microscopy of human urine and purified Tamm-Horsfall's glycoprotein. Scand J Urol Nephrol 22:313-315
45. Grant AM, Neuberger A (1973) The turnover rate of rabbit urinary Tamm-Horsfall glycoprotein. Biochem J 136:659668

46. Brown D, Waneck GL (1992) Glycosyl-phosphatidylinositol-anchored membrane proteins. J Am Soc Nephrol 3:895-906 (Editorial)

47. Fukuoka S, Freedman SD, Yu H, Sukhatme VP, Scheele GA (1992) GP-2/THP gene family encodes self-binding glycosylphosphatidylinositol-anchored proteins in apical secretory compartments of pancreas and kidney (erratum Proc Natl Acad Sci U S A 1992, 89:3669). Proc Natl Acad Sci U S A 89:1189-1193

48. Rindler MJ, Naik SS, Li N, Hoops TC, Peraldi MN (1990) Uromodulin (Tamm-Horsfall glycoprotein/uromucoid) is a phosphatidylinositol- linked membrane protein. J Biol Chem 265:20784-20789

49. Mattey M, Naftalin L (1992) Mechanoelectrical transduction, ion movement and water stasis in uromodulin. Experientia 48:975-980

50. Biava C, Grossman A, West M (1966) Ultrastructural observations on renal glycogen in normal and pathologic human kidneys. Lab Invest 15:330-356

51. Lee JB, Vance VK, Cahill GF (1962) Metabolism of C14labeled substrates by rabbit kidney cortex and medulla. Am J Physiol 203:27-36

52. Flyvbjerg A, Marshall SM, Frystyk J, Hansen KW, Harris AG, Orskov H (1992) Octreotide administration in diabetic rats: effects on renal hypertrophy and urinary albumin excretion. Kidney Int 41:805-812

53. Hostetter TH, Meyer 'TW, Rennke HG, Brenner BM (1986) Chronic effects of dietary protein in the rat with intact and reduced renal mass. Kidney Int 30:509-517

54. Rambausek M, Dulawa J, Jann K, Ritz E (1988) TammHorsfall glycoprotein in diabetes mellitus: abnormal chemical composition and colloid stability. Eur J Clin Invest 18:237-242

55. Dulawa J, Rambausek M, Jann K, Notohamiprodjo M, Ritz $\mathrm{E}$ (1985) Abnormal radiofurosemide binding by TammHorsfall glycoprotein of diabetic patients. Diabetologia 28:827-830

56. Mogensen CE, Andersen MJ (1973) Increased kidney size and glomerular filtration rate in early juvenile diabetes. Diabetes 22:706-712

57. Jensen PK, Kristensen KS, Rasch R, Persson AE (1988) Decreased sensitivity of the tubuloglomerular feedback mechanism in experimental diabetic rats. In: Persson AE, Boberg U (eds) The juxtaglomerular apparatus. Elsevier Science, Amsterdam, pp 333-338

58. Hostetter TH, Troy JL, Brenner BM (1981) Glomerular hemodynamics in experimental diabetes mellitus. Kidney Int 19:410-415

59. Kumar S, Muchmore A (1990) Tamm-Horsfall protein-uromodulin (1950-1990). Kidney Int 37:1395-1401

60. Pinto M, Oron C, Pinto O, Peer G (1990) Natural autoantibodies against Tamm-Horsfall glycoprotein in normal individuals in relation to age and in adult patients with kidney diseases. Jpn J Exp Med 60:197-202

61. Mauer SM, Steffes MW, Michael AF, Brown DM (1976) Studies of diabetic nephropathy in animals and man. Diabetes $25: 850-857$ 